\title{
Response of "Red Globe” (Vitis vinifera L.) to cane girdling
}

\author{
Oğuzhan Soltekin ${ }^{1}$, Turcan Teker ${ }^{1}$, Adnan Erdem ${ }^{1}$, Ege Kacar $^{2}$, and Ahmet Altindişli ${ }^{2}$ \\ ${ }^{1}$ Manisa Viticulture Research Station, Manisa, Turkey \\ ${ }^{2}$ Ege University, Faculty of Agriculture, Department of Horticulture, Izmir, Turkey
}

\begin{abstract}
The effect of cane girdling on skin colour, harvest date, yield, and some quality characteristics of Vitis vinifera L. cv. Red Globe table grape variety, was measured over two growing seasons, 2013-2014, at the facility of Manisa Viticulture Research Station in Turkey. Cane girdling was performed on the spurs after first bud was left from the bottom and $4 \mathrm{~mm}$-wide ring of bark was completely removed with a doubleded knife at veraison period. Statistical analyses showed that total soluble solid content, berry width, berry length, colour parameters, CIRG index and anthocyanin content of the Red Globe was significantly affected by the girdling treatment in both years, 2013 and 2014. In addition it was detected that any effect of girdling treatments cannot be determined statistically significant on total yield, marketable yield, total phenolics, titrable acidity, $\mathrm{pH}$ and 50 berry weight. Total and marketable yields of girdled vines had higher value although they weren't statistically significant. Furthermore it was observed on girdled vines 7 and 11 days earliness compare to the control vines in 2013 and 2014, respectively.
\end{abstract}

\section{Introduction}

Grape (Vitis vinifera L.) is considered as one of the most important commercial fruit crops of temperate to tropical regions [1]. The grape is gaining popularity for its high nutritive value, excellent in taste, multipurpose use and better returns [2].

Turkey lies on the most convenient temperate zone for viticulture around the world is among the countries which have a voice throughout the world with its vineyard and yield values. Today, almost 77 million tonnes of world grape production that is almost 4 million tonnes are yielded in Turkey [3] and this production is characterized as primary table grapes (53\%) and as secondary raisin yield (35\%) [4]. Table grape production relies upon numerous viticultural practices to ensure good yield and superior quality. There are lots of factors in grape growing enter into the production of quality such as pruning, crop load, thinning, girdling, topping, pinching and using of plant growth regulators [5]. In other words biological properties and quality of food is under the influence of some agricultural practices.

Girdling is one of the important treatments which involves removal of a strip of phloem (about $4 \mathrm{~mm}$ in width) from either stem or cane [5]. First practiced on grapevines in 1745 [6], girdling has been found to increase berry weight [7-9] and set $[10,11]$ and to advance fruit maturity $[8,9,12]$.

Desired quality in table grapes represents a combination of medium-sized clusters of uniformly large, perfect berries with the characteristic colour, pleasing flavor and texture of the variety [5]. Physical properties of products such as colour, form and shape are more important for consumers [13].

Grapes are girdled at berry set to increase berry size or at veraison (berry softening or colour break) to advance sugar and colour development. The increase in berry size due to girdling may result from better carbohydrate nutrition above the girdle as the transport of sugars from leaves to the root system is effectively blocked [14]. Alternatively, changes in the hormone balance of the vine after girdling may have a role on increasing berry size [15]. Also girdling of the grapevine has been reported to improve berry colour development and to stimulate rapid ripening in grapes [5].

This study has been conducted on Red Globe ( $V$. vinifera L.) grape variety to determine the effect of girdling treatment on maturity, berry colouration, quality parameters and yield.

\section{Materials and methods}

The research was carried out on the field that was built through north and south sides belonging to Directorate of Manisa Viticulture Research Station, during 2013 and 2014 seasons. This field supposedly at the centre of Manisa is located between $38^{\circ} 04^{\prime}-39^{\circ} 58^{\prime}$ North latitudes and $27^{\circ} 08^{\prime}-29^{\circ} 05^{\prime}$ East longitudes. As the plant material Red Globe grape variety was grafted onto 1103 Paulsen rootstock. Grafted vines planted in 2004 with $3 \times 3$ m row spaces and trained to rational pergola systems. Canopy height of the pergola system was $2.20 \mathrm{~m}$. At the time of the winter pruning, the vines were cordon-pruned and leaving 4 cordons and there were 5 arms of $3 / 4$ spurs on each cordon.

There were two applications; Girdling (G) and Control (C) treatments. Girdling treatment was performed at veraison. Also there was no application for Control. Cane girdling was performed on the spurs after first bud was left from the bottom. $4 \mathrm{~mm}$-wide ring of bark was completely removed with a doubleded knife. Control vines were left 
Table 1. Effects of girdling on TSS, pH, TA, Berry Weight, Berry width, Berry length, Marketable yield ratio, Total yield in 2013 season.

\begin{tabular}{|c|c|c|c|c|c|c|c|c|}
\hline & TSS (\%) & pH & TA $(g / 1 t)$ & $\begin{array}{c}50 \text { Berry } \\
\text { Weight (g) }\end{array}$ & $\begin{array}{c}\text { Berry width } \\
\text { (mm) }\end{array}$ & $\begin{array}{c}\text { Berry length } \\
(\mathrm{mm})\end{array}$ & $\begin{array}{c}\text { Marketable } \\
\text { yield ratio (\%) }\end{array}$ & Total yield (g) \\
\hline $\mathrm{C}$ & $16.40 \mathrm{~b}$ & 4.09 & 3.27 & 479.07 & $20.28 b$ & $22.66 \mathrm{~b}$ & 74.51 & 28188.67 \\
\hline G & $18.27 \mathrm{a}$ & 4.20 & 2.92 & 511.29 & $26.19 \mathrm{a}$ & $26.33 \mathrm{a}$ & 82.24 & 29811.67 \\
\hline $\mathrm{P}$ & $*$ & \multirow[b]{2}{*}{ ns } & \multirow{2}{*}{ ns } & \multirow{2}{*}{ ns } & $* *$ & $* *$ & \multirow{2}{*}{ ns } & \multirow{2}{*}{ ns } \\
\hline LSD & 1.409 & & & & 2.844 & 3.270 & & \\
\hline
\end{tabular}

G: Girdling treatment; C: Control; Ns: non-significant, $* p<0.05, * * p<0.01$.

untouched. Every application consisted of three replicates of 2 vines. When the clusters on the control vines reached to about $18{ }^{\circ} \mathrm{Bx}$, harvest was done and all samples were immediately brought to the laboratory for analysis.

\subsection{Measured parameters}

After harvesting, total yield $(\mathrm{g})$ and marketable yield ratio (\%) were determined and 50 berries were sampled from each replication, then sampled berries from each replication were weighed and average berry weight $(\mathrm{g})$ was determined. Berry width and berry length $(\mathrm{mm})$ were measured by using caliper compass and colour measurements (L, a, b, Chr, Hue) were made by Minolta Co (CR-300). Also CIRG index (Color Index of Red Grapes) was estimated according to the [16]. Berries were squeezed for each replication and the percentage of total soluble solids percentage (TSS\%) was measured by the Refractometer. Also juice $\mathrm{pH}$ was measured by $\mathrm{pH}$ meter and total anthocyanin with phenolic contents were determined according to the [17]. Total titratable acidity percentage (TA\%) was measured by titrating the berry juice with $0.1 \mathrm{~N} \mathrm{NaOH}$. The TA\% was expressed as grams of tartaric acid per $100 \mathrm{ml}$ of juice [18].

The experimental design was randomized parcels with three replicates. Analysis of variance was implemented to research data by using TARIST statistical analysis software package on computer, and in order to determine the differences among averages, LSD test was implemented on importance level of $5 \%$ and $1 \%$.

\section{Results}

First year, the effect of girdling application on TSS and Anthocyanin content was statistically significant $(p<0.05)$. When the girdling treated vines had $20.01 \mathrm{mg} /$ $\mathrm{kg}$ anthocyanin content averagely, the control vines only had $8.3 \mathrm{mg} / \mathrm{kg}$ (Tables 1 and 2). Also TSS\% of girdled vines was above the control vines and it was observed on girdled vines 7 days earliness compare to the control vines (Table 1).

Tables 1 and 2 show that effect of girdling treatment on berry width, berry length and CIRG index was statistically significant $(p<0.01)$ while it was non-significant in terms of ph, TA, berry weight, total phenolics, total yield and marketable yield ratio. In terms of berry width and berry length, girdled vines had higher values 26.19 and $26.33 \mathrm{~mm}$ than control vines, $20.28 \mathrm{~mm}$ and $22.66 \mathrm{~mm}$, respectively. Also CIRG index value was found 3.93 with girdling treatment while it was found 1.91 in control vines. Girdled vines had higher values in terms of 50 berry weight, total phenolics, total yield and marketable yield ratio compare to the control vines although effect of girdling was found statistically non significant.

In the second year, effect of girdling treatment on TSS, berry length, anthocyanin content and marketable yield ratio was statistically significant $(p<0.05)$ (Tables 3 and 4). According to the TSS values, it was observed that girdling application accelerates ripening. Furthermore girdled vines had higher berry length $(26.95 \mathrm{~mm})$, anthocyanin content $(20.01 \mathrm{mg} / \mathrm{kg})$ and marketable yield ratio $(74.82 \%)$.

Results in Tables 3 and 4, showed that effect of girdling treatment on berry width and CIRG index was found statistically significant $(p<0.01)$ and it was observed that these parameters were increased by girdling treatment. In terms of total yield and total phenolics, girdling effect was found statistically non significant but higher values were observed in girdled vines in comparison to control vines.

Table 2. Effects of girdling on colour parameters (L, a, b, Chr, HUE), CIRG index, total anthocyanin and total phenolics in 2013 season.

\begin{tabular}{|c|c|c|c|c|c|c|c|c|}
\hline & $\mathbf{L}$ & $\mathbf{a}$ & b & Chroma & HUE & CIRG index & $\begin{array}{c}\text { Total anthocyanin } \\
(\mathrm{mg} / \mathrm{kg})\end{array}$ & $\begin{array}{c}\text { Total phenolics } \\
\text { (mg/kg) }\end{array}$ \\
\hline $\mathrm{C}$ & $46.91 \mathrm{a}$ & $4.53 b$ & $7.30 \mathrm{a}$ & 9.39 & $72.89 \mathrm{a}$ & $1.91 \mathrm{~b}$ & $8.30 \mathrm{~b}$ & 505.95 \\
\hline $\mathrm{G}$ & $29.13 b$ & $10.85 \mathrm{a}$ & $1.82 \mathrm{~b}$ & 8.04 & $34.20 \mathrm{~b}$ & $3.93 \mathrm{a}$ & $20.04 \mathrm{a}$ & 585.30 \\
\hline $\mathrm{P}$ & $* *$ & $* *$ & $*$ & \multirow{2}{*}{$\mathrm{ns}$} & $* *$ & $* *$ & $*$ & \multirow{2}{*}{ ns } \\
\hline LSD & 11.302 & 4.928 & 3.466 & & 9.253 & 0.715 & 7.388 & \\
\hline
\end{tabular}

G: Girdling treatment, C: Control, Ns: non-significant, $* p<0.05, * * p<0.01$. 
Table 3. Effects of girdling on TSS, pH, TA, Berry weight, Berry width, Berry length, Marketable yield ratio, Total yield in 2014 season.

\begin{tabular}{|c|c|c|c|c|c|c|c|c|}
\hline & TSS (\%) & pH & TA (g/lt) & $\begin{array}{c}50 \text { Berry } \\
\text { weight }(g)\end{array}$ & $\begin{array}{c}\text { Berry } \\
\text { width }(\mathbf{m m})\end{array}$ & $\begin{array}{c}\text { Berry length } \\
\text { (mm) }\end{array}$ & $\begin{array}{c}\text { Marketable } \\
\text { yield ratio }(\%)\end{array}$ & Total yield (g) \\
\hline $\mathrm{C}$ & $15.25 b$ & 3.95 & 3.51 & 475.14 & $22.11 \mathrm{~b}$ & $23.62 b$ & $71.267 \mathrm{~b}$ & 16973.33 \\
\hline $\mathrm{G}$ & $16.45 \mathrm{a}$ & 3.95 & 3.68 & 452.76 & $25.55 \mathrm{a}$ & $26.95 \mathrm{a}$ & $74.817 \mathrm{a}$ & 24090.00 \\
\hline $\mathrm{P}$ & $*$ & \multirow{2}{*}{ ns } & \multirow{2}{*}{ ns } & \multirow{2}{*}{ ns } & $* *$ & $*$ & $*$ & \multirow{2}{*}{ ns } \\
\hline LSD & 0.848 & & & & 2.278 & 2.334 & 3.528 & \\
\hline
\end{tabular}

G: Girdling treatment; C: Control; Ns: non-significant, * $p<0.05$, ** $p<0.01$.

Table 4. Effects of girdling on colour parameters (L, a, b, Chr, HUE), CIRG index, Total anthocyanin and Total phenolics in 2014 season.

\begin{tabular}{|c|c|c|c|c|c|c|c|c|}
\hline & $\mathbf{L}$ & $\mathbf{a}$ & b & Chroma & HUE & $\begin{array}{l}\text { CIRG } \\
\text { index }\end{array}$ & $\begin{array}{c}\text { Total anthocyanin } \\
(\mathbf{m g} / \mathbf{k g})\end{array}$ & $\begin{array}{c}\text { Total phenolics } \\
\text { (mg/kg) }\end{array}$ \\
\hline $\mathrm{C}$ & $37.93 \mathrm{a}$ & 8.69 & 0.363 & $8.81 \mathrm{a}$ & $95.14 \mathrm{a}$ & $1.82 \mathrm{~b}$ & $7.80 \mathrm{~b}$ & 515.46 \\
\hline G & $26.92 b$ & 7.25 & -0.593 & $5.05 \mathrm{~b}$ & $46.63 b$ & $4.21 \mathrm{a}$ & $20.01 \mathrm{a}$ & 613.46 \\
\hline $\mathrm{P}$ & $* *$ & \multirow{2}{*}{$\mathrm{ns}$} & \multirow{2}{*}{$\mathrm{ns}$} & $* *$ & $* *$ & $* *$ & $*$ & \multirow{2}{*}{ ns } \\
\hline LSD & 7.496 & & & 2.264 & 14.179 & 1.480 & 11.448 & \\
\hline
\end{tabular}

G: Girdling treatment; C: Control; Ns: non-significant, $* p<0.05, * * p<0.01$.

\section{Discussions}

Girdling, as practiced in commercial vineyards, consists of removing a narrow ring of bark entirely round some member of the vine. The ring can be removed from the trunk, the arms, the fruit canes or the spurs but common treatments is done on either the trunk or the individual fruit canes. Girdling the trunk affects the entire vine, whereas girdling a cane affects only the part of the cane above the girdle. The width of cane girdles used commercially averages $4.8 \mathrm{~mm}$ [19].

Generally, vines are girdled to accomplish for improving fruit setting, maturation and yield as well as physical and chemical properties of fruits. The best-known effect of girdling is to interrupt the movement through the phloem of photosynthates produced by leaves. This increases carbohydrates and plant hormones in above parts of the girdle $[20,14]$. Each of these effects may be obtained by complete girdling at the proper time. The stage at which the operation is performed is probably the greatest single factor in determining the nature and magnitude of the effect obtained [19]. Interruption of phloem translocation of photosynthates to the root system is known to improve carbohydrate availability to bunches, thereby enhancing sugar accumulation of seeded grapes and berry size of seedless grapes [5]. To achieve this, girdling has to be performed at the onset of berry ripening, i.e. veraison, when rates of sugar accumulation in berries are highest $[21,22,14]$. When the TSS values have been examined, it has been stated that girdling application accelerates ripening. It was observed on girdled vines 7 and 11 days earliness compare to the control vines in 2013 and 2014, respectively. Thus our results are similar with the findings of [20] who reported that sugar contents increased in phloem ringed plants compared to the control.
As can be seen from the results, berry width and berry length were increased with girdling treatment in both two years. In the first year $29.17 \%$ and $16.19 \%$ increment were obtained from the girdled vines compare to the control vines while $15.55 \%$ and $14.07 \%$ increment were determined in second year for berry width and berry length parameters, respectively. In a study girdling grapevines increases carbohydrate concentration above girdle and resulted in larger berries as the transport of sugars from leaves to the root system is effectively blocked [14]. Girdling at berry set has been reported by several investigators to increase in berry size, and especially in seedless varieties $[23,24]$ but our results showed girdling in veraison had significant response to enhance berry dimensions for Red Globe variety.

Berry colour is one of the most important quality factors for table grapes [23] and also the variety Red Globe frequently produces unevenly coloured bunches. In our research, girdling treatments had better berry colour parameters and induced more uniform colouration in both two years. Especially higher CIRG Index values were obtained from girdled vines. This outcome confirms earlier studies. For example [22] reported that girdling improves colouring and [19] indicated that girdling at veraison hasten ripening and to improve skin colour.

Anthocyanins are responsible for the colour of the red and black grape berries and their concentration in the berry skin increases during berry ripening [25]. Grape berry colour development has been reported to be influenced by a number of factors such as cultivar, cultural practices, location as well as exogenous application of abscisic acid and ethephon and girdling [26]. Girdling of the grapevine has been reported to increase berry anthocyanins compared to control and similar results were obtained with girdling treatment on red table grape "Aki Queeen" [27].

Our results showed non-significant response with girdling treatment in terms of total yield, marketable yield 
ratio and total phenolics content. Similar results were obtained by [28] in Turkey. They reported that girdling treatments had non-significant effects on yield of "Trakya İkeren" table grapes.

\section{Conclusion}

Girdling treatments on "Red Globe" grapevines can produce desirable increases in berry width, berry length and colour parameters, especially CIRG index and anthocyanin content. Furthermore girdling at veraison accelerates ripenning and provide earliness over two years. Therefore this treatment may offer a new opportunity for sustainable commercial production of Red Globe table grapes. In addition we observed positive effects of girdling on total yield, marketable yield and total phenolics. However it would be practiced to obtain better yield and fruit composition with proper time of the treatments.

\section{References}

[1] V. N. Gowda, S. A. Keshava, and S. Shyamalamma. Acta Hort. 785, p: 207-211. (2008).

[2] S. N. Ghosh, Tarai R. and P. Pal. Acta Hort. 785, p:73-77. (2008).

[3] FAO, Food and Agriculture Organization of United Nations. Available online at: http: / / faostat 3 . fao.org/download/Q/*/E. (2013). Access date: 29.04.2015.

[4] TUIK, Türkiye istatistik kurumu. Available online at: http://tuikapp.tuik.gov.tr/bitkiselapp/bitkisel . zul . (2013). Accessdate: 29.04.2015.

[5] A.J. Winkler, J.A. Cook, W.M. Kliewer, and L.A. Lider. General Viticulture, Unv of California Press: Berkeley. (1974).

[6] G. Hussman. Orange Judd Co., New York, N.Y. (1898).

[7] D.C. Harrell and L.E. Williams. Amer. J. Enol. Viticult. 38, p:83-88. (1987).

[8] H.E. Jacob. Proc. Amer. Soc. Hort. Sci. 25, p:223-229. (1928)

[9] R.J. Weaver. Proc. Amer. Soc. Hort. Sci. 65, p:183186. (1955).
[10] H.E. Jacob. Calif. Agr. Ext. Serv. Circ. 56, p:1-18. (1931).

[11] L.A. Lider and G.W. Sanderson. Proc. Amer. Soc. Hort.Sci. 74, p:383-387. (1959).

[12] T.J. Zabadal. HortScience 27(9), p:975-976. (1992).

[13] F. J. Francis. Agricultural and food chemistry: past, present, future. p 260-279. AVI Pub. Co. Westport, CT, USA. (1978).

[14] T. Roper, and L. Williams. Plant Physiol., 89, p:1136-1140. (1989).

[15] P. E. Kriedemann and F. Lenz. Vitis 11, p:197-207. (1972).

[16] J. Carreño, A. Martinez, L. Almela, J.A. FernandezLopez. Food Res. Int. 28, p:373-377. (1995).

[17] B. Cemeroğlu. Meyve ve Sebze İsleme Endüstrisinde Temel Analiz Metotları. BILTAV Yayınları No: 02-2, p:381, Ankara. (1992).

[18] R.J. Weaver and A.J. Winkler. Plant Physiology, 27(3), p:626-630. (1951).

[19] A.J. Winkler. General viticulture. Univ. of Calif. Press, Berkeley. p:293-300. (1962).

[20] M.M. Khandaker, A.S. Hossain, N. Osman and A.N. Boyce. Int. Jour. of agriculture and biology, ISSN Print: 1560-8530. (2011).

[21] R. J. Weaver, S.B. Mccune. Hilgardia 28, p:297-350. (1959).

[22] W. F. Peacock, J. Jensen, J. Else, G. Leavitt. Amer. J. Enol. Viticult. 28, p:228-230. (1977).

[23] N. Nikolaou, E. Zioziou, D. Stravrakas and A. Patakas. Australian Journ. of Grape and Wine Research, 9, p:12-14, (2003).

[24] N. Dokoozlian, D. Luvisi, M.M. Moriyama. and P.L. Schrader. California, Agriculture, 49, Nu:2, p:237-240. (1994).

[25] M.G. Mullins, A. Bouquet and L.E. Williams. Biology of the Grapevine. Cambridge University Press. ISBN-10: 0521305071. (1992).

[26] M.O. Downey, N.K. Dokoozlian and M.P. Krstic. Am. J. Enol. Vitic., 57, p:257-268. (2006).

[27] T. Yamane and K. Shibayama. Journal of the Japanese society for horticulture science. 75, Issue: 6, p:439-444. (2006).

[28] B. İşççi and A. Altındişli. Journal of Agricultural Faculty of Gaziosmanpasa University. ISSN:1300 2910. 31(3), p:91-100. (2014). 